\title{
Significance and Effect of Ecological Rehabilitation Project in Inland River Basins in Northwest China
}

\author{
Yu Wang • Qi Feng $\cdot$ Lijuan Chen • \\ Tengfei Yu
}

Received: 4 May 2012/Accepted: 9 April 2013/Published online: 29 May 2013

(C) The Author(s) 2013. This article is published with open access at Springerlink.com

\begin{abstract}
The Ecological Water Transfer and Rehabilitation Project in the arid inland area of northwest China is an important measure in restoring a deteriorated ecosystem. However, the sustainability of the project is affected by many socio-economic factors. This article examines the attitudes of the local populace toward the project, its impact on the livelihood of the people, and the positive effects of water-efficient agricultural practices in Ejina County. Related data were collected through questionnaire surveys and group discussions. The results identified three critical issues that may influence the sustainability of the project in the study area. The first issue relates to the impact of the project on the livelihood of local herdsmen. The potential for the sustainability of the project is compromised because the livelihood of the herdsmen greatly depends on the compensation awarded by the project. The second issue is that the project did not raise the water resource utilization ratio, which may undermine its final
\end{abstract}

Y. Wang $(\bowtie) \cdot$ Q. Feng $\cdot$ L. Chen

Cold and Arid Regions Environmental and Engineering

Research Institute, Chinese Academy of Sciences, West

Donggang Rd 320, Lanzhou 730000, Gansu Province, China

e-mail: wangyu-mike@163.com

Y. Wang

School of Energy and Power Engineering, Lanzhou University of Technology, Langongping Rd 287, Lanzhou 730050,

Gansu Province, China

Q. Feng

Alashan Desert Eco-Hydrology Experimental Research Station, West Donggang Rd 320, Lanzhou 730000, Gansu Province,

China

T. Yu

Schools of Resources and Environment, Lanzhou University, South Tianshui Rd 222, Lanzhou 730000, China purpose. Finally, the compensation provided by the project considers losses in agriculture, but neglects the externalities and public benefit of eco-water. Thus, appropriate compensation mechanisms should be established and adopted according to local economic, environmental, and social conditions. Some recommendations for improving the sustainability of the project are provided based on the results of this study.

Keywords Arid region - Ecological restoration . Sustainable development $\cdot$ Livelihood

\section{Introduction}

The dual impacts of anthropogenic activities and possibly in the longer-term climate change are common in the arid inland zones of northwest China. This is particularly the case in the lower reaches of rivers, and result is severe degradation of the ecological environment: rivers become intermittent; water quality is degraded; groundwater levels decline; plant communities decrease; and the area undergoing desertification increases. (Feng and others 2005; Ma and others 2005; Richardson and others 2007; Wang and Cheng 2000). In groundwater-dependent ecosystems, the dynamics of soil moisture, relative to the water table fluctuations, control the overall ecosystem dynamics (Tamea and others 2009). Additionally, all services provided by these ecosystems may be threatened when the riparian ecosystems are subject to insufficient river water supplies (Stromberg and others 2007). Therefore, water transfers that involves both ecological aspects and rehabilitation needs must be considered (Eamus and others 2006). However, people living in and adjacent to ecological restoration areas are highly dependent on the water 
resources for food (Qin and others 2006; Pote and others 2006), grassland for livestock (Fan and others 2005), and other products (Fabricius and Burger 1997). The concerns regarding water resource shortages have resulted in conflicts between the water demands of the local populace and the water requirements of the environment. Similarly, some aspects of water requirements for ecological restoration and the development of local communities can be in conflict (Maikhuri and others 2000; Oltremari and Jackson 2006).

For ecological restoration projects, ignoring the interests of the local populace and excluding them from the planning, management, and decision-making processes can result in conflict (Lewis 1996; Nepal 2002; Xu and others 2006; Cao and others 2009). After several projects much of the restored vegetation was converted back to farmland and rangeland at the end of the project, compromising the environmental achievements that had been made (Chen and others 2002; Cao and others 2007). Thus, this issue necessitates community participation and equality in the decision-making processes (IUCN 1993).

Most research on ecological restoration areas in China has focused on flora and fauna, addressing problems from the perspective of the reserve managers or the government (Han 2000; Miao 2000; Wu and others 2002). This typical top-down management style has marginalized the benefits to the local populace and paid little attention to the role of local participation in protected area planning, management, and decision-making (Harkness 1998; Miao 2000). Therefore, a systematic evaluation of the effectiveness of the conservation practices has been highlighted as a key component of advancing scientific management for conservation (Sutherland 2000).

The Ecological Water Transfer and Rehabilitation Project (EWTRP) is a comprehensive project that includes ecological water transfer, grazing bans, ecologically motivated relocation/resettlement (ERR) of herdsmen, and the development of water-efficient agricultural practices. The EWTRP is located in the arid inland area of northwest China and was launched in 2000 to cover three inland river basins: the Tarim River basin, Heihe River basin, and Shiyang River basin (Chen and others 2011; Guo and others 2009). After 10 years this project has achieved obvious ecological benefits (Xi and others 2010; Huang and Pang 2010; Hou and others 2007; Jiang and Liu 2009; $\mathrm{Xu}$ and others 2003a). In the Tarim River and Heihe River Basins, for example, water table levels have increased significantly, biodiversity has increased, and vegetation has recovered by more than $80 \%$, significantly curbing desertification. Despite its potential for improving the regional and local ecological environments, the sustainability of the project is affected by several socio-economic factors, including the readjustment of economic restructure and the economic compensation and employment of local farmers and herdsmen. Most program plots are located in impoverished regions of China and grazing bans have led to severe shrinkage in the parts of the economy that are based on livestock grazing. Consequently, illegal or informal herding, which could eventually ruin the recovered pastures (Fan and others 2005), has become the main method of augmenting income for those relocated. Additionally, those relocated herdsmen have difficulty finding jobs because of their low skills level (Xun and Bao 2008). Compensation paid for ecological restoration cannot cover the loss to farmers and headsmen of returning farmland to forest and, as a result, the farmers return and deforest and re-cultivates the land. Consequently ecological recovery becomes a victim in the vicious poverty cycle (Cao and others 2009).

To determine farmers' perceptions of these impacts, we surveyed rural farmers to investigate concerns related to their income and their attitudes towards the EWTRP. We focused on how the EWTRP affected local livelihoods and whether the policies could potentially contribute better to a socially embedded practice of restoration by determining the key factors responsible for public acceptance of the policies. The principal objectives of this study were: (1) measuring the endorsement of EWTRP by the stakeholders; (2) measuring the influence of EWTRP on the livelihood of the residents; (3) evaluating the effect of the project on the development of water-efficient agricultural practices; and (4) proposing potentially useful recommendations for enduring ecological restoration area management. The study is located in Ejina County, Inner Mongolia, China (Fig. 1), a key region of the EWTRP in the Heihe River Basin and an area which it can be argued is representative of the entire region.

\section{Materials and Methods}

\section{Study Area}

Ejina County is located in western Inner Mongolia on the downstream reach of the Heihe River $\left(97^{\circ} 10^{\prime}-103^{\circ} 7^{\prime} \mathrm{E}\right.$, $\left.39^{\circ} 52^{\prime}-42^{\circ} 47^{\prime} \mathrm{N}\right)$. The area has a typical continental arid climate. The mean annual precipitation for the period from 1957-2001 was $38.9 \mathrm{~mm}$ and the mean annual pan evaporation was $3,653 \mathrm{~mm}$. With low precipitation, high pan evaporation, extreme temperature differences, and long durations of sunlight. The Ejina Oasis formed by the Heihe River flowing through the Badanjilin desert can reduce wind erosion and weaken dust storms. Hence, it is considered an ecological safety barrier of the Alashan, Hexi Corridor in northern China. 
Fig. 1 Study area, sampling sites

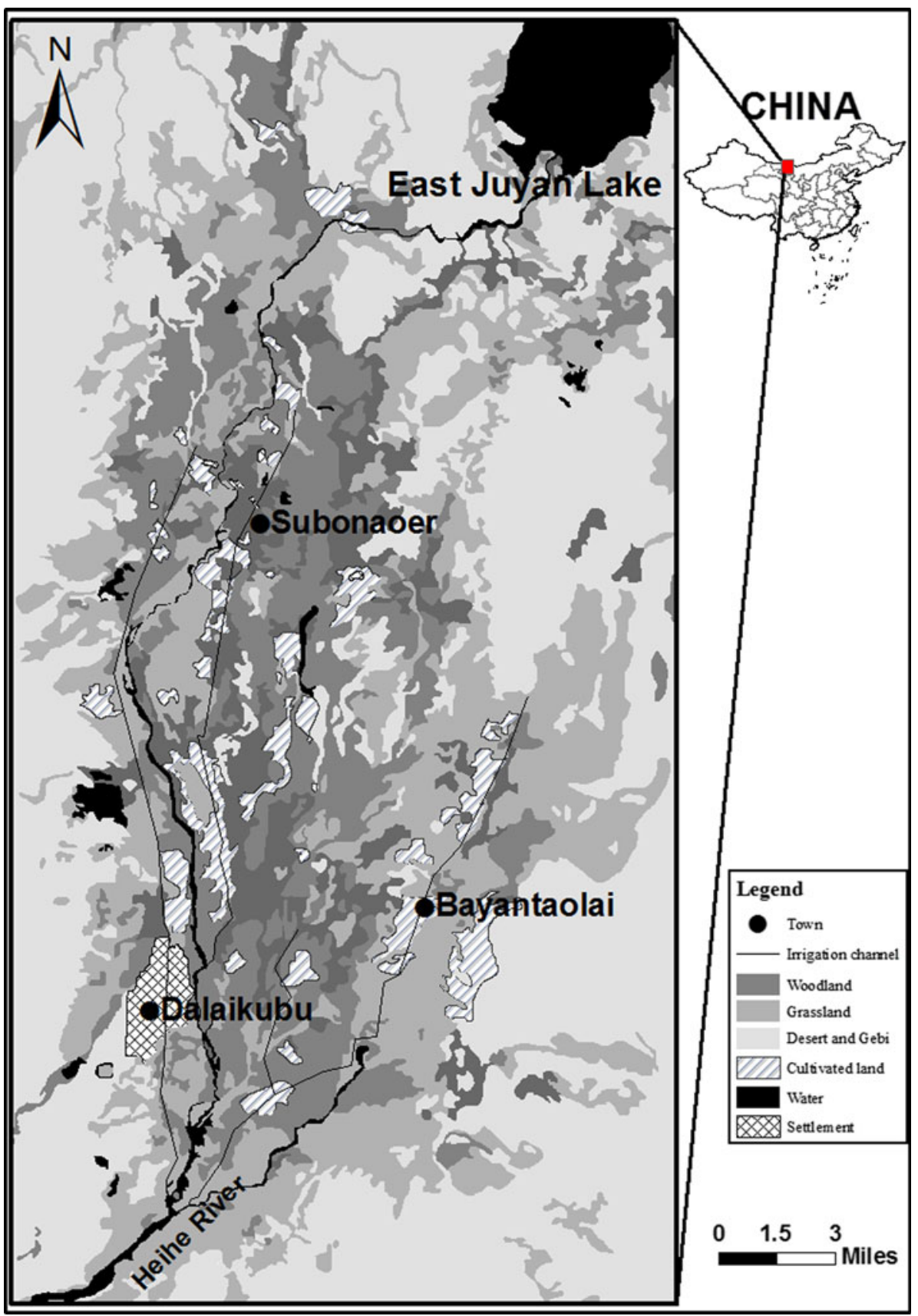

In 2006 the five townships and an agricultural zone under the jurisdiction of the Ejina County had a total population of more than 5,700 in 1,349 households. Most of these belonged to Mongolian and Han ethnic groups, although Hui, Tibetan, and Manchu were also represented. The populace in Ejina County depends mainly on traditional agriculture for subsistence. Cotton and Hami melon are the main crops, and camels and sheep are the principal livestock raised. Hami melon and sheep provide the major sources of income. Other employment opportunities in the region include construction, transportation, collection of Chinese herbal medicines, and forest protection.
Over the last 50 years the upper reaches of the Heihe river basin have been subject to large-scale land and water resource development projects. Coupled with a lack of effective coordinated management of water resources, the amount of water flowing into the downstream region has continually decreased. In addition, over-grazing and overcultivation has resulted in the deterioration of the ecological environment in Ejina, as evidenced by rivers and lakes going dry, lowering of the water table, deterioration of water quality, degradation of vegetation, and losses of biodiversity. The desertification process exacerbated the deterioration of the ecological environment and the area 
has evolved into a source of dust storms, which pose a threat to environmental safety in northern China (Feng and Cheng 1998; Xu and others 2003b).

The Chinese government set up the Heihe Basin Authority in 1999 for the uniform distribution of water throughout the basin and for diverting water downstream to Ejina County to alleviate the deteriorating ecological environment and to preserve the Ejina oasis. Before this project water was used mainly for forest and grassland irrigation, groundwater recharge, and replenishment of the downstream river reaches East Juyan Lake. In this project to ensure sufficient supplies for the ecological system, water transfer during critical periods was not used for agricultural irrigation (Lu and others 2011). Additionally, to improve water use efficiency and restore the deteriorating ecological environment, Ejina County implemented bans on grazing and (Spell out abbreviation) ERR of herdsmen, and developed water-efficient agricultural practices.

\section{Data Collection}

Of the six administrative areas in Ejina County, three were selected for this study: Dalaikubu, Bayantaolai (an agricultural demonstration zone near Dalaikubu), and Subonaoer.

The research was carried out using questionnaires administered as personal interviews in September and October 2010. One adult ( $\geq 18$ years old) from each household was interviewed in his or her residence. Stratified sampling, based on spatial distribution and the different aspects of project implementation, was used to ensure proportional representation of households in the regions. For example, the Bayantaolai area focused on developing water-efficient agricultural practices; Dlaikubu received persons relocated under the ERR; and Subonaoer is characterized by agriculture-livestock production operations. A total of 350 households were randomly selected from the three towns and 346 households were successfully interviewed.

A separate face-to-face survey was used to improve the efficiency and reliability of the questionnaire survey and to avoid interventions from external officials. A questionnaire with both fixed-response and open-ended questions was used. The fixed-response questions and the possible alternative answers were read to the interviewees and the answers recorded. The open-ended questions were subsequently asked to and the answers taken down. The purpose of this qualitative data was to gain an in-depth understanding of the respondents answers. The survey was pre-tested the survey to identify and correct any problem relative to how the questions were phrased. The survey was then revised, as needed, to resolve these problems.
Our survey investigated the relationship of the questionnaire responses to rural demographic factors (i.e., age, sex, education, occupation, family size, family income, and compensation of the respondents), attitudes of local residents, and resulting concerns raised by the implementation of EWTRP, as well as the promotion of water-efficient agricultural practices (Table 1).

\section{Data Analysis}

Binary logistic regression models are often used for analyzing individual decision-making when the dependent variable has only two values. In this study, we analyzed the factors affecting farmers' support of the EWTRP; farmers' livelihoods; the use of grazing on reclaimed land after compensation; and farmers' participation in water-efficient agricultural practices. At the same time, we used qualitative data to enrich our quantitative results, which could not capture local farmers' attitudes and incentives towards the EWTRP.

The dependent variable delineating the willingness of farmers to participate had values of 0 and 1 , with 0 representing unwillingness and 1 representing willingness. We recorded respondents' responses based on the assumption that a neutral response can indicate a potentially negative attitude (Newmark and others 1993; Gillingham and Lee 1999). The major socio-economic characteristics of the survey are summarized in Table 2 and the survey results are shown in Table 3.

We examined the survey data using a backward conditional logistic regression. First, all independent variables were input into the regression model to determine whether the respondents' gender (GEN), age (AGE), education level (EDU), occupation (OCC), household size (HHS), individual income (INC), and compensation (COM) were independently associated with an individual's attitudes towards the EWTRP. Independent variables that had no significant correlations with dependent variables were eliminated, and the test was then continued until the independent variables had a significant impact on the dependent variables. As a default, SPSS uses a probability of entry of 0.05 and a probability of removal of 0.10 (SPSS Inc., Chicago, Ill.). The full model is as follows:

$$
\begin{aligned}
\operatorname{Logit}(p)= & B_{0}+B_{1} \mathrm{GEN}+B_{2} \mathrm{AGE}+B_{3} \mathrm{EDU}+B_{4} \mathrm{OCC} \\
& +B_{5} \mathrm{HHS}+B_{6} \mathrm{INC}+B_{7} \mathrm{COM}
\end{aligned}
$$

where $p$ is the probability of response variable; $\operatorname{Logit}(p)$ is $\ln (p / 1-p)$ or the logarithm of odds; $B_{0}$ through $B_{7}$ are coefficients of the explanatory variables; and $e^{\mathrm{B}}$ is the odds ratio, a measure of likely change in the probability of the response variable because of change in the explanatory 
Table 1 Questionnaire

\begin{tabular}{|c|c|c|}
\hline Number & Question & Response \\
\hline 1 & Do you know the EWTRP? & $\mathrm{No} / \mathrm{Yes}$ \\
\hline 2 & Do you support to EWTRP? & $\mathrm{No} / \mathrm{Yes}$ \\
\hline 3 & $\begin{array}{l}\text { Ever since water transfer and } \\
\text { ecological rehabilitation, do } \\
\text { you think the local environment } \\
\text { changed better? }\end{array}$ & $\mathrm{No} / \mathrm{Yes}$ \\
\hline 4 & $\begin{array}{l}\text { Does the EWTRP affect your } \\
\text { livelihood? }\end{array}$ & $\begin{array}{l}\text { No/Yes/No } \\
\text { opinion }\end{array}$ \\
\hline 5 & $\begin{array}{l}\text { Does the compensation can make } \\
\text { up your economic losses for limited } \\
\text { farmland, forests, and animal } \\
\text { husbandry? }\end{array}$ & $\begin{array}{l}\text { No/Yes/No } \\
\text { opinion }\end{array}$ \\
\hline 6 & $\begin{array}{l}\text { Will you once again reclaim grazing } \\
\text { after compensation? }\end{array}$ & $\begin{array}{l}\text { No/Yes/No } \\
\text { opinion }\end{array}$ \\
\hline 7 & $\begin{array}{l}\text { Does the EWTRP cause the amount } \\
\text { of surplus labor of your family? }\end{array}$ & $\begin{array}{l}\text { No/Yes/No } \\
\text { opinion }\end{array}$ \\
\hline & $\begin{array}{l}\text { If the EWTRP creates the amount of } \\
\text { surplus labor, how do you arrange? }\end{array}$ & Open \\
\hline 8 & $\begin{array}{l}\text { As an important part of the EWTRP, } \\
\text { would you like to participate in } \\
\text { water-efficient agricultural practices? }\end{array}$ & $\begin{array}{l}\text { No/Yes/No } \\
\text { opinion }\end{array}$ \\
\hline 9 & $\begin{array}{l}\text { As an important EWTRP measures, } \\
\text { are you satisfied with the current } \\
\text { water irrigation channels? }\end{array}$ & $\begin{array}{l}\text { No/Yes/No } \\
\text { opinion }\end{array}$ \\
\hline 10 & $\begin{array}{l}\text { As an important EWTRP measures, } \\
\text { are you satisfied with the current } \\
\text { price of water? }\end{array}$ & $\begin{array}{l}\text { No/Yes/No } \\
\text { opinion }\end{array}$ \\
\hline \multirow[t]{2}{*}{11} & $\begin{array}{l}\text { Do you think ecological water transfer } \\
\text { and rehabilitation project promote } \\
\text { water-efficient agricultural practices? }\end{array}$ & $\begin{array}{l}\text { No/Yes/No } \\
\text { opinion }\end{array}$ \\
\hline & $\begin{array}{l}\text { What are the constraining factors in the } \\
\text { development of water-efficient } \\
\text { agricultural practices? (multiple-choice) }\end{array}$ & Open \\
\hline
\end{tabular}

Table 2 Demographic data and characteristics of the sample

\begin{tabular}{llllll}
\hline Characteristic & Group & \multicolumn{2}{l}{ Craft } & Total (\%) \\
\cline { 3 - 5 } & & Peasant & Herdsmen & Other \\
\hline Gender & Male & 127 & 53 & 33 & $213(61.6)$ \\
& Female & 43 & 47 & 43 & $133(38.4)$ \\
Age & $<35$ & 70 & 43 & 30 & $143(41.3)$ \\
& $36-50$ & 60 & 33 & 47 & $140(40.5)$ \\
\multirow{2}{*}{ Education } & $>50$ & 40 & 23 & 0 & $63(18.2)$ \\
level & Primary & 44 & 31 & 8 & $83(24.0)$ \\
& Middle & 92 & 43 & 20 & $155(44.8)$ \\
& High & 33 & 27 & 48 & $108(31.2)$ \\
& school & & & & \\
\hline
\end{tabular}

variable from one value to the next. Five logistic regression models were developed (Table 4).

\section{Results}

Demographic Variables

A total of 213 men $(61.6 \%)$ and 133 women $(38.4 \%)$ were interviewed. The ages of the respondents were between 18 and 69, with an average of 40. The 18-35 yearold group was the largest, followed by the $36-50$ and 51-69 years old. About $24 \%$ of the respondents were illiterate or at the primary school level, $44.8 \%$ were junior middle school level, and $31.2 \%$ were high school level or above. The occupations of the respondents include $49.1 \%$ engaged in agricultural activities, $28.9 \%$ engaged in grazing activities, and $22 \%$ engaged in forestry activities or rural grass-roots management activities. Individual incomes are generally shared among family members in China, thus, we calculated the individual income as the total household income divided by the number of individuals in the household. The average household income of the local residents was USD $\$ 4,419$ and the per capita income was USD $\$ 1,059$ (USD $\$ 1=$ Renminbi (RMB) 6.6997 in 2010).

\section{Attitude of Respondents to EWTRP}

The attitude of the community residents towards EWTRP directly affects the implementation of the project. Respondents indicated that they were familiar with the policies of EWTRP (94.2\%) and that they supported the project $(57.8 \%)$. In total, $79.8 \%$ of the people agreed that the local ecological environment has significantly improved after implementing the EWTRP (Table 3).

The main reason for supporting the project is that every herdsman older than 21 receives USD \$1,493 compensation each year for ERR due to grazing bans and the protection of the forests. Additionally, a few farmer households involved in forest protection and management earn USD \$74.6 per month in wages. There have been substantial changes in the vegetative cover and groundwater levels downstream of the Heihe River after nearly 10 years of project implementation (Xi and others 2010). Grassland desertification has been effectively curbed, farming and livestock production has been maintained at normal levels, and farmers and herdsmen have received the benefits from the restoration of the environment. 
Table 3 Survey results

\begin{tabular}{|c|c|c|c|c|}
\hline \multirow[t]{2}{*}{ Number } & \multirow[t]{2}{*}{ Content } & \multicolumn{3}{|l|}{ Answer } \\
\hline & & Yes & No & No opinion \\
\hline 1 & Do you know the EWTRP? & $326(94.2 \%)$ & $20(5.8 \%)$ & \\
\hline 2 & Do you support to EWTRP? & $200(57.8 \%)$ & $146(42.2 \%)$ & \\
\hline 3 & $\begin{array}{l}\text { Ever since water transfer and } \\
\text { ecological rehabilitation, do you think } \\
\text { the local environment changed better? }\end{array}$ & $276(79.8 \%)$ & $70(20.2 \%)$ & \\
\hline 4 & Does the EWTRP affect your livelihood & $180(52.1 \%)$ & $146(42.2 \%)$ & $20(5.7 \%)$ \\
\hline 5 & $\begin{array}{l}\text { Does compensation can make up your } \\
\text { economic losses for limited grazing } \\
\text { farmland and forests, animal husbandry? }\end{array}$ & $163(47.1 \%)$ & $173(50 \%)$ & $10(2.9 \%)$ \\
\hline 6 & $\begin{array}{l}\text { Will you once again reclaim grazing after } \\
\text { compensation }\end{array}$ & $130(37.6 \%)$ & $190(54.9 \%)$ & $26(7.5 \%)$ \\
\hline 7 & $\begin{array}{l}\text { Does EWTRP cause the amount of } \\
\text { surplus labor of your family? }\end{array}$ & $150(43.4 \%)$ & $160(46.2 \%)$ & $36(10.4 \%)$ \\
\hline 8 & $\begin{array}{l}\text { As an important part of the EWTRP, } \\
\text { would you like to participate in } \\
\text { water-efficient agricultural practices? }\end{array}$ & $237(68.5 \%)$ & $56(16.2 \%)$ & $53(15.3 \%)$ \\
\hline 9 & $\begin{array}{l}\text { As an important EWTRP measures, } \\
\text { are you satisfied with the current } \\
\text { water irrigation channels? }\end{array}$ & $107(30.9 \%)$ & $230(66.5 \%)$ & $9(2.6 \%)$ \\
\hline 10 & $\begin{array}{l}\text { As an important EWTRP measures, } \\
\text { are you satisfied with the current } \\
\text { price of water? }\end{array}$ & $276(79.8 \%)$ & $60(17.3 \%)$ & $10(2.9 \%)$ \\
\hline 11 & $\begin{array}{l}\text { Do you think ecological water transfer } \\
\text { and rehabilitation project promote } \\
\text { water-efficient agricultural practices? }\end{array}$ & $70(20.2 \%)$ & $260(75.1 \%)$ & $16(4.7 \%)$ \\
\hline
\end{tabular}

Some residents (42.2\%), however, do not support the project (Table 3). The logistic regression analysis (Table 4, Model A) shows that occupation, age, individual income, and compensation were the main factors for the lack of support. The herdsmen who were relocated and lowincome individuals generally did not agree with the project. Older respondents and those that received more compensation were more likely to support the project.

\section{Influence of EWTRP on Residents' Livelihood}

The EWTRP improved the local ecological environment and also affected the livelihoods of the local residents. A majority $(52.1 \%)$ of the respondents believed that the project had positively affected their normal lives and livelihoods. Half of the respondents believed that the compensation given as a result of the cultivation and grazing bans and the protection of the forest could not compensate for the economic losses they incurred. Chinese regulations permit compensation under the project to last only for 10 years. This is a concern among the residents since there was no plan devised to replace the income sources lost due to the farming and grazing bans. As such, about $37.6 \%$ of the respondents indicated that if the compensation was stopped, they would again cultivate and graze the grasslands or forests. This response illustrates that the sustainability of the project may be at risk.

To protect or restore the degraded grassland ecosystems, herdsmen in the HeiHe River basin were relocated by the Chinese government from traditional grazing lands to agricultural or urban areas in 2001. Although the ERR can mitigate the damage caused by humans to the fragile ecosystems and provide recovery and restoration opportunities for these ecosystems, it also raises many issues. Because the type of animal production was changed, many herdsmen switched from traditional grazing to rearing livestock in feedlots, reducing the number of laborers required for feeding and causing higher unemployment. Due to limited investment, much of the infrastructure (e.g., water, electricity, roads, hospitals, schools) of the immigrant villages was inadequate and due to cultural differences, many of those relocated could not adapt to urban life (Mao and others 2012).

Overall $43.4 \%$ of the families had experienced unemployment due to the limitations in animal husbandry and relocations. This surplus labor moved to the cities to find work (16\%), engaged in slack farming seasonal work (20.7\%), animal husbandry $(22.4 \%)$, animal product processing $(5.2 \%)$, forest management $(18.4 \%)$, tourism $(7.8 \%)$, or Chinese herbal medicine collection $(9.5 \%)$. 
Table 4 Results of the analysis of the responses on the factors influencing attitudes toward EWTRP with the Logistic model

\begin{tabular}{|c|c|c|}
\hline Model & $\begin{array}{l}\text { Logistic regression } \\
\text { equations }\end{array}$ & $\begin{array}{l}\text { Levels of } \\
\text { significance }\end{array}$ \\
\hline $\begin{array}{l}\text { (a) Model A: Farmers' support } \\
\text { of the EWTRP }\end{array}$ & $\begin{array}{l}\text { Logit }(\mathrm{p})_{\text {support }}=24.646+3.412 \mathrm{AGE}-2.535 \mathrm{OCC} \\
+22.2 \mathrm{INC}+1.605 \mathrm{COM}\end{array}$ & 0.05 \\
\hline $\begin{array}{l}\text { (b) Model B: Affect farmers' } \\
\text { livelihood }\end{array}$ & $\begin{array}{l}\text { Logit }(\mathrm{p})_{\text {livelihood }}=-2.497+3.506 \mathrm{OCC} \\
\quad+1.724 \mathrm{INC}+2.837 \mathrm{COM}\end{array}$ & 0.05 \\
\hline $\begin{array}{l}\text { (c) Model } C \text { : whether again reclaim } \\
\text { grazing after compensation }\end{array}$ & $\begin{array}{l}\text { Logit }(p)_{\text {recultivation }}=2.661+2.086 \mathrm{AGE}+1.468 \\
\text { EDU-2.711INC }+0.062 \mathrm{COM}\end{array}$ & 0.05 \\
\hline $\begin{array}{l}\text { (d) Model } D \text { : Participation in the } \\
\text { water-efficient agricultural practices }\end{array}$ & $\begin{array}{l}\text { Logit }(\mathrm{p})_{\text {participation }}=-44.207-7.983 \mathrm{AGE} \\
\quad+0.858 \mathrm{EDU}-17.845 \text { OCC }+2.964 \mathrm{INC}\end{array}$ & 0.05 \\
\hline $\begin{array}{l}\text { (e) Model E: Promote development } \\
\text { of the water-efficient agricultural } \\
\text { practices }\end{array}$ & $\begin{array}{l}\text { Logit }(\mathrm{p})_{\text {development }}=40.301-5.589 \mathrm{GEN} \\
\quad+3.891 \mathrm{AGE}-17.765 \mathrm{INC}\end{array}$ & 0.05 \\
\hline
\end{tabular}

The logistic regression analysis (Table 4 Model B) showed that occupation, compensation, and individual income are the main factors affecting the livelihood of the residents. Herdsmen and young families (i.e., parents with one or two children) were the groups most affected by the policy of reverting farmlands to forests and limiting grazing. Some herdsmen were relocated to the village and the number of livestock decreased after opportunities for livestock grazing became limited. The herdsmen changed their production methods from grazing to processing large quantities of products, and were encouraged to adopt shed feeding (Pan and others 2006). However, investigations showed that the cost of shed feeding was too high and that processing industry of livestock products in the area did not create a large enterprise. Government incentives were unsuccessful, causing the herdsmen to live only on the compensation earned from limited farming and grazing, as well as a small portion of income from land.

Education level, age, and the continuity of compensation are the main factors influencing the attitudes toward regrazing and re-cultivation (Table 4 Model $\mathrm{C}$ ). As the age increases and the education levels become higher, the population generally abandons the desire for grazing land reclamation.

\section{EWTRP Promotion of Water-Efficient Agricultural}

Practices

The goals of EWTRP were to provide solutions for water shortages in the downstream areas, improve water use efficiency, and restore the deteriorated ecological environment. Developing water-efficient agricultural practices is one of the best solutions for improving water use efficiencies (Cheng and others 2008). A series of water-efficient agricultural practices were implemented, including constructing irrigation channels, increasing water rates, improving water management, adjusting the agricultural planting structure, and developing water-efficient agricultural technologies (e.g., drip irrigation). The role that EWTRP played in the promotion of water-efficient agricultural practices was examined (Table 3). Most respondents $(68.5 \%)$ were pleased to participate in water-saving agriculture and were satisfied $(79.8 \%)$ with the current price of water. However, a majority $(66.5 \%)$ were not satisfied with the irrigation channels and believe that the channel design is unreasonable and that their management is poor. Only a few $(20.2 \%)$ believe that EWTRP promotes the water-efficient agricultural practices.

The local government readjusted the agriculture planting structure, thus, farmers in Ejina mainly planted cotton and Hami melon. Some of the farmers built the drip irrigation project and gained better benefits, but this practice did not gain popular support. The main factors limiting the development of water-efficient agricultural practices are the difficulty in mastering the techniques of water-efficient agricultural practices $(12.5 \%)$; the large investment needed (i.e., the difficulty of the local populace in bearing the high costs) (35.6\%); and the falling prices of agricultural products, which discourages investment in water-efficient irrigation projects $(20.8 \%)$. Also, since China implemented the Household Responsibility System (HRS), each farmer has not a single plot of land, but small, fragmented plots of different sizes. Due to the high incidence of land fragmentation, mechanized farming is difficult; thus, $21.8 \%$ of the people are not willing to develop waterefficient technologies. Approximately $7.4 \%$ of the local farmers exhibited a lack of awareness of water conservation and hoped to use more water. Finally, low water prices have led to the misuse of water resources $(1.9 \%)$.

Logistic regression analysis (Table 4, Model D) showed that education level, age, occupation, and individual income are important factors influencing participation in water-efficient irrigation practices. Those with high incomes and education levels (i.e., young people and 
farmers) would like to participate in these practices. In addition, gender, education level, and individual income were associated with attitudes promoting the development of water-efficient agricultural practices (Table 4, Model E). More male respondents with higher education levels supported water-efficient irrigation compared with female respondents with lower education levels. However, respondents with high individual incomes claim that EWTRP did not promote the development of water-efficient agricultural practices.

\section{Discussion}

Sustainability of EWTRP and Livelihoods of Farmer Households

Although most people had positive attitudes and admitted that EWTRP restored the deteriorated ecological environment, they were not optimistic with regard to future man-water relationships and ecological restoration. Most herdsmen noted that the compensation for the grazing bans could not make up for what they lost. They complained that the government managers cared more about revegetation than the welfare of the local populace. The compensation received cannot make up for their losses, especially for the young families (who receive only USD \$2,986), since their living expenses include their daily subsistence and their children's educational expenses. These responses indicated that the function of ecological restoration is effective, but the functions of social and economic development were marginalized. As such, the local populace may adopt actions detrimental to the ecological objectives if their interests are marginalized over a longer period (Maikhuri and others 2001).

Respondents with high education levels objectively expressed opinions about EWTRP (i.e., it brought both benefits and losses). They benefited from the project because they have the opportunity to work in other areas. By contrast, less-educated farmers who moved to cities to seek employment often found themselves unqualified for available jobs and were then forced to accept low-paying jobs, such as those requiring manual labor. The awareness of the older respondents regarding environmental protection had gradually increased. Wang and others (2005) noted that urbanization or living near a road helps those relocated obtain more living skills (Wang and others 2005). In our investigation, however, emigrants were not able to adapt to urbanization development and became poorer due to lack of the necessary cultural integration. This also implies that relocation not only moves the herdsman from grassland to the cities, but also weakens cultural and social integration.

Farming is a rational economic enterprise whose fundamental aim, from a business perspective, is to seek maximum benefit. The ecological restoration policy can play a role in this activity, but only if the economic interests of farmers can be accommodated. Conflicts may arise when the perspective of the state or other institutions and the points of view or demands of the local farmers differ. These conflicts will often render the implementation of national land conservation strategies or land use policies difficult, or even impossible to implement (Biot and others 1995). The personal interests of those relocated for ecological protection have led to increasing concerns on future livelihoods and employment opportunities. Several laborers have been idle due to lack of job training and employment guidance. They cannot find other employment opportunities, thus, deforestation and grazing were their only options (Fan and others 2005). In addition, impoverished pastoralists intensely depended on local natural resources, thus, they will return to their original ways of life resulting in the loss of the effectiveness of ecological management and the reverting of the ecological environment to a poorer state when the government compensation ends (Cao and others 2010; Beeton and Lynch 2012).

The main purpose of EWTRP is to protect the environment, while allowing local residents to enjoy stable lives and gradually become prosperous. The livelihood and economic development needs of those relocated should be addressed to achieve sustainability goals. Thus, continual investment in financial, human, and social capital, and culture for the restoration of damaged ecosystems has become essential to ensure ecological sustainability.

\section{Promotion of EWTRP and Development of Water-} Efficient Agricultural Practices

Water resources are scarce in arid areas. The protection and restoration of an ecological system needs a process to provide reasonable coordination of the ecological and agricultural water uses to protect the ecological environment and provide sustainable economic development. In the Heihe River basin, EWTRP was implemented to improve the efficiency of water use and restore the ecological environment. Therefore, the development of waterefficient agricultural practices can effectively address the conflicts between ecological water and agro-pastoral water. However, several factors limit the smooth development of these practices. Although local government adjusted the structure of agricultural plantings, the farmers mainly plant cash crops that have high water consumption; forage crops are generally planted in a lower proportion. This irrational planting structure exacerbates water shortages for ecological restoration. From the perspective of sustainable utilization of water resources, Ejina County is suitable for the cultivation of forage grasses. Fodder production could provide much high-quality forage for livestock production, 
enhance vegetation coverage, and reduce land desertification. The development of a forage production industry in an agricultural area could alleviate the pressures from livestock in natural rangeland and decrease grassland degradation. The development of the fodder and livestock production industries could result in the construction of special bases for livestock production, which would benefit economic development and the incomes of herdsmen.

Theory predicts that as a resource becomes scarcer, resource-conserving technologies are more likely to be adopted (Ruttan and Hayami 1984). Development of waterefficient agricultural practices is essential to solving the problems of water shortages in China's inland river basins. Application of new technologies and efficient water resource management are important components of waterefficient agriculture practices (Xu and Gong 2009). The adoption of technologies by farmers may reflect rational decision-making based on farmers' perceptions of the appropriateness and value of the technologies in the coming years. Farmers tend to adopt technologies as long as they can realize an increase in expected profitability (de Graaff and others 2008). However, low-value agricultural products and high equipment costs in the region have led farmers to only partially adopt the drip irrigation project. Lack of water conservation skills and fragmented land area also contribute to farmers' reluctance to adopt new technologies. Therefore, government support is a key factor influencing attitudes toward the use of advanced water-efficient irrigation technology. As an important part of the EWTRP, policy makers should fully consider investing in water-efficient agricultural facilities and providing farmers with technical training.

Irrigation management is systems engineering. However, local administrators still currently follow the original irrigation management methods: the canal system is not well maintained; the enthusiasm of the managers on all levels is not high; water use is not standardized; and the water conservation consciousness of the people is not strong. Much of the reason for this can be attributed to the low cost of irrigation water in the Heihe River Basin. The cost of irrigation water is mainly based on the irrigated area because of the difficulty in flow measurement and metering. No relationship has been established between a farmer's water conservation and cost-savings, making the price lever difficult to implement and hindering the popularization of water-efficient irrigation practices.

\section{Compensation for Ecological Water Resources}

Ecological water resources have the properties of public goods, but the distribution of their costs and benefits are not balanced. The costs are borne mostly by the local populace, whereas the benefits are shared by people at all levels, including local, regional, national, and even global levels
(Wells 1992; Omezzine and Lokman 1998). The latter represents environmental externalities because most people enjoy the benefits, but bear no cost. (For example, dust storms that originated in Ejina County endanger the health of the residents of eastern cities in China, but local farmers bear the costs of returning farmland to forests and grazing bans for eco-environment restoration.) Only farming and grazing losses are currently considered when developing compensation for those who stop cultivation, ban grazing, and establish public forests. No consideration has been given to ecological benefits, and their regional or national effects. Therefore, effective mechanisms must be designed so that a greater proportion of the global benefit of the forests can be captured to benefit both the endangered ecosystem and the welfare of the local communities (Ferraro and Kiss 2002).

In Ejina County compensation for participating in the effort to limit farming and grazing is based on agricultural production. It does not take into consideration the spatial and temporal ecological benefits. This effort requires government departments to formulate a corresponding legal system to internalize the external phenomena of water resources, to force beneficiaries to pay fees for the compensation for the loss of natural water resources ( $\mathrm{Lu}$ and Ma 2010). Beneficiaries that provide appropriate economic compensation for the protector are required by the fair principle and are the embodiment of social justice (Zhou and others 2005). The losers receive their compensation according to the principle of legal and environmental justice if the beneficiaries pay the fees. Damaged and restricted development areas provide the compensation for ecological water resources and economic incentives, which will be more favorable to the economic and ecological development.

According to the economic characteristics of publicity and externality of water resources and considering that the compensators fairly enjoy the rights and obligations to build an ecological compensation system with water resource as a link, these actions will support sustainable development in the region. In arid areas, the economy is less developed and government compensation should play a leading role. Increasing the financial and technical inputs of ecological water transfer and rehabilitation projects while implementing ecological compensation for water resources and supporting the development of water-efficient agricultural practices are important ways to resolve the ecological restoration problem in arid areas.

\section{Conclusion}

The improvement and reconstruction of the ecological environment is a complex systems engineering problem 
requiring the consideration of ecological, social, economic, and cultural factors. Its key is to realize the balanced sustainable development (Qin 2012). The purposes of this study were to probe the perceptions of the local populace and to advance the balanced development of the environment and the benefits to the local populace. The results offer some valuable information that can be incorporated into governmental decision-making to help resolve the conflicts in the arid areas.

Although most people had a positive attitude and supported the EWTRP (almost certainly because the local populace recognizes the need to restore the area), they found their livelihoods have been greatly affected. The most vulnerable residents (those with the lowest net incomes and low education levels-young families and those relocated) are faced with risks caused by EWTRP. They have fewer opportunities to find new jobs in the absence of job creation and training projects and lack income-replacement payments and cultural integration. As a result of these failures, much of the vegetation restored during the period of EWTRP is at risk of being re-converted into farmland and rangeland at the end of EWTRP, thereby compromising the environmental sustainability and achievements of the project. Due to the unreasonable agricultural planting structure and low water use efficiency, the project to improve water use did not play its expected role.

As a long-term ecological restoration project, the EWTRP has inevitably produced conflicts in the struggle for water between ecological and agricultural needs. As the project continues, this dilemma is expected to gradually increase. Water resource shortages will become more pronounced and, thereby, increase the risks of regional ecological degradation and desertification. The compensation given considers only losses in agriculture and in animal husbandry; no consideration has been given to the imbalance in the ecological benefit of water resources regionally or nationally.

To achieve long-term sustainability, resource managers and policy makers must commit to taking an integrated view in evaluating and implementing policies to achieve longterm benefits. Some of the issues can be partially solved by adopting a more comprehensive policy that does not exclusively focus on financial compensation. From a livelihood perspective, it is urgent to develop employment opportunities and education/training programs to reduce opportunity costs of the project and increase local economic benefits, which in turn will decrease pressure on ecological restoration aspects. In addition, the construction of infrastructure and cultural integration of those relocated should be strengthened. From a water conservation perspective, local governments should increase investment in waterefficient agricultural facilities and provide farmers with technical training; improve water resources management; and adjust the agricultural planting structure to fit the characteristics of the local environment and economic development. Finally, reasonable water resources compensation mechanisms should be established and all values of water resources for the ecological restoration should be incorporated into the cost-benefit evaluation to avoid an unequal spatial distribution of the costs and benefits.

Acknowledgments This work was supported by the National Natural Science Foundation of China (91025002), the Key Research Program of the Chinese Academy of Sciences (KZZD-EW-04-05), the Team Interaction and Cooperation of the Science and Technology Program of the Chinese Academy of Sciences and West Light Foundation of The Chinese Academy of Sciences. The author wishes to thank the anonymous reviewers for their reading of the manuscript, and for their suggestions and critical comments.

Open Access This article is distributed under the terms of the Creative Commons Attribution License which permits any use, distribution, and reproduction in any medium, provided the original author(s) and the source are credited.

\section{References}

Beeton RJS, Lynch AJJ (2012) Most of nature: a framework to resolve the twin dilemmas of the decline of nature and rural communities. Environ Sci Policy 23:45-56

Biot Y, Blaikie PM, Jackson C, Palmer-Jones R (1995) Rethinking research on land degradation in developing countries. World Bank Discussion Paper 289. The World Bank, Washington DC

Cao S, Chen L, Liu Z (2007) Disharmony between society and environmental carrying capacity: a historical review, with an emphasis on China. Ambio 36(5):409-415

Cao S, Xu CG, Chen L, Wang XQ (2009) Attitudes of farmers in China's northern Shaanxi Province towards the land-use changes required under the Grain for Green Project, and implications for the project's success. Land Use Policy 26:1182-1194

Cao S, Wang XQ, Song YZ, Chen L, Feng Q (2010) Impacts of the Natural Forest Conservation Program on the livelihoods of residents of Northwestern China: perceptions of residents affected by the program. Ecol Econ 69:1454-1462

Chen Q, Wang K, Qi S (2002) Dynamics of land use and changes of sloping field productivity in hilly and gully area of Loess Plateau in Xiji County, Ningxia. J Soil Water Conserv 16:28-29 (in Chinese)

Chen YN, Ye ZX, Shen YJ (2011) Desiccation of the Tarim River, Xinjiang, China, and mitigation strategy. Quat Int 244:264-271

Cheng GD, Xiao HL, Li CZ, Ren J, Wang S (2008) Water-saving ecoagriculture and integrated water resources management in Heihe River Basin, northwest China. Adv Earth Sci 23(7):661-665 (in Chinese)

de Graaff J, Amsalu A, Bodnár F, Kessler A, Posthumus H, Tenge A (2008) Factors influencing adoption and continued use of longterm soil and water conservation measures in five developing countries. Appl Geogr 28:271-280

Eamus D, Froend R, Loomes R, Hose G, Murray B (2006) A functional methodology for determining the groundwater regime needed to maintain the health of groundwater-dependent vegetation. Aust J Bot 54:97-114

Fabricius C, Burger M (1997) Comparison between a nature reserve and adjacent communal land in xeric succulent thicket: an indigenous plant user's perspective. S Afr J Sci 93(6):259-262 
Fan SY, Zhou LH, Ma YH (2005) Environmental protection policy effect on households: a case study as Yanchi County. China Popul Resour Environ 15(5):124-128 (in Chinese)

Feng Q, Cheng GD (1998) Current situation, problems and rational utilization of water resources in arid north-western China. J Arid Environ 40:373-382

Feng Q, Liu W, Si JH, Su YH, Zhang YW, Cang ZQ, Xi HY (2005) Environmental effects of water resources development and use in the Tarim River basin of northwestern China. Environ Geol 48:202-210

Ferraro PJ, Kiss A (2002) Direct payments to conserve biodiversity. Science 28:1718-1719

Gillingham S, Lee PC (1999) The impact of wildlife related benefits on the conservation attitude of local people around the Selous Game Reserve, Tanzania. Environ Conserv 26:218-228

Guo QL, Feng Q, Li JL (2009) Environmental changes after ecological water conveyance in the lower reaches of Heihe River, northwest China. Environ Geol 58:1387-1396

Han N (2000) A policy study on sustainable management for China's nature reserves. J Nat Resour 15(3):201-207 (in Chinese)

Harkness J (1998) Recent trends in forestry and conservation of biodiversity in China. China Q 156:911-934

Hou P, Beeton RJ, Carter RW, Dong XG, Li X (2007) Response to environmental flows in the lower Tarim River, Xinjiang, China: ground water. J Environ Manage 83:371-382

Huang TM, Pang ZH (2010) Changes in groundwater induced by water diversion in the Lower Tarim River, Xinjiang Uygur, NW China: evidence from environmental isotopes and water chemistry. J Hydrol 387:188-201

IUCN (International Union for Conservation of Nature) (1993) Parks for life: report of the fourth World Congress on National Parks and Protected Areas, 10-21 February 1992. IUCN, Gland

Jiang XH, Liu CM (2009) The response of vegetation to water transport in the lower reaches of the Heihe river. Acta Geographica Sinica 64(7):791-797 (in Chinese)

Lewis C (1996) Managing conflicts in protected areas. IUCN, Gland

Lu WC, Ma YX (2010) Studies on interest compensation mechanisms for the coordination of the water resource utilization. China Popul Resour Environ 20(11):54-59

Lu ZY, Tan DS, Zheng B, Zhu CQ (2011) Post-evaluation of the ecological impact of water diversion and recent management in the downstream Heihe River. Acta Scientiae Circumstantiae 31(7):1556-1561 (in Chinese)

Ma JZ, Wang XS, Edmunds WM (2005) The characteristics of ground-water resources and their changes under the impacts of human activity in the arid Northwest China-a case study of the Shiyang River Basin. J Arid Environ 61:277-295

Maikhuri RK, Nautiyal S, Rao KS, Chandrasekhar K, Gavali R, Saxena KG (2000) Analysis and resolution of protected areapeople conflicts in Nanda Devi Biosphere Reserve, India. Environ Conserv 27(1):43-53

Maikhuri RK, Nautiyal S, Rao KS, Saxena KG (2001) Conservation policy-people conflicts: a case study from Nanda Devi Biosphere Reserve, India. For Policy Econ 2:355-365

Miao H (2000) Community participation mechanism of china's nature reserve. In: China Man and Biosphere Committee (eds), Study of sustainable management policies for China's nature reserve. Scientific and Technical Documents Publishing House, Beijing, pp 57-71 (in Chinese)

Nepal SK (2002) Involving indigenous peoples in protected area management: comparative perspectives from Nepal, Thailand, and China. Environ Manage 30(6):748-763

Newmark WD, Leonard NL, Sariko HI, Gamassa DGM (1993) Conservation attitudes of local people living adjacent to five protected areas in Tanzania. Biol Conserv 63:177-183
Oltremari JV, Jackson RG (2006) Conflicts, perceptions, and expectations of indigenous communities associated with natural areas in Chile. Nat Areas J 26(2):215-220

Omezzine A, Lokman Z (1998) Management of modern irrigation systems in Oman: allocative vs. irrigation efficiency. Agric Water Manage 37:99-107

Pan SB, Lu JX, Zhang JL, Sun T (2006) Analysis on ecological environment protection and its effectiveness of E'jina Oasis in Heihe River Basin. Geog Geo-Inf Sci 22(5):106-112 (in Chinese)

Pote J, Shackleton C, Cocks M, Lubke R (2006) Fuelwood harvesting and selection in Valley Thicket, South Africa. J Arid Environ 67(2):270-287

Qin SS (2012) An analysis of Hu Jintao's thought on science and technology. J Northeastern Univ (Social Sci) 3:251-255 (in Chinese)

Qin DY, Lu X, Zhang ZP, Liu J (2006) Influence of short-term management on ecological environment and regional food security in the Heihe River Basin. J Hydraulic Eng 37(10): 1278-1282 (in Chinese)

Richardson DM, Holmes PM, Esler KJ, Galatowitsch SM, Stromberg JC, Kirkman SP, Pyšek P, Hobbs RJ (2007) Riparian vegetation: degradation, alien plant invasions, and restoration prospects. Divers Distrib 13:126-139

Ruttan VW, Hayami Y (1984) Toward a theory of induced institutional innovation. J Dev Stud 20(4):203-223

Stromberg JC, Beauchamp VB, Dixon MD, Lite SJ, Paradzick C (2007) Importance of low-flow and high-flow characteristics to restoration of riparian vegetation along rivers in arid southwestern United States. Freshw Biol 52:651-679

Sutherland W (2000) The conservation handbook: research, policy, and management. Blackwell, Oxford

Tamea S, Laio F, Ridolfi L, D'Odorico P, Rodriguez-Iturbe I (2009) Ecohydrology of groundwater-dependent ecosystems: 2. Stochastic soil moisture dynamics. Water Resour Res 45:W05420. doi:10.1029/2008WR007293

Wang G, Cheng G (2000) The characteristics of water resources and the changes of the hydrological process and environment in the arid zone of northwest China. Environ Geol 39:783-790

Wang T, Chen GT, Dong ZB, Chui Y, Fu GZ, Xing GC (2005) Model of controlling aeolian desertification and benefits analysis in Balinyou Banner, Inner Mongolia. J Desert Res 25(5):750-756 (in Chinese)

Wells M (1992) Biodiversity conservation, affluence and poverty: mismatched costs and benefits and effort to remedy them. Ambio 21(3):237-243

Wu XM, Xu H, Jiang M, Liu L (2002) Harmonized development of nature reserve and local communities. Rural Eco-Environ 18(2):10-13 (in Chinese)

Xi HY, Feng Q, Liu W, Si JH, Chang ZQ, Su YH (2010) The research of groundwater flow model in Ejina Basin, Northwestern China. Environ Earth Sci 60:953-963

$\mathrm{Xu} \mathrm{D}$, Gong SH (2009) Trends and priorities in study of modern agricultural efficient water use technologies. Eng J Wuhan Univ 42(5):554-581 (in Chinese)

Xu HL, Chen YN, Li WH (2003a) Study on response of groundwater after ecological water transport at the lower reaches of the Tarim River. Res Environ Sci 16(3):19-38 (in Chinese)

Xu ZM, Cheng GD, Zhang ZQ, Su ZY, Loomis J (2003b) Applying contingent valuation in China to measure the total economic value of restoring ecosystem services in Ejina region. Ecol Econ 44:345-358

Xu JY, Chen LD, Lu YH, Fu BJ (2006) Local people's perceptions as decision support for protected area management in Wolong Biosphere Reserve, China. J Environ Manage 78:362-372 
Xun LL, Bao ZM (2008) Government, market and households in the ecological relocation process: a sociological analysis of ecological relocation in S banner. Social Sci China 29:113-128
Zhou DJ, Dong WJ, Sun LY, Shi DH, Qi Y (2005) Ecological compensation in management of water resources of the river basins. J Beijing Normal Univ (Social Sci Ed) 4:131-145 (in Chinese) 